\title{
Finding "Health" and "Meaning" in Texas-Sized Turnover: Application of Seminal Management Principles for Administration and Research in U.S. Public Child Welfare Agencies
}

\author{
Nicole Willis \\ Nancy Chavkin \\ Patrick Leung
}

\begin{abstract}
Public child welfare agencies in the United States have struggled with high turnover rates, especially among caseworkers. Research has explored turnover in terms of negative organizational outcomes, and efforts have been developed to reduce overall turnover rates. However, there has been little change in turnover rates in the last 30 years. The public child welfare system is inclined to higher turnover due to the unique nature of the work. Efforts to reduce the overall turnover rate fail to recognize the heterogeneity and healthy aspects of turnover unique to public child welfare organizations, which present challenges for both practice and research. By critically questioning how turnover is socially constructed, measured, and addressed, and integrating seminal management principles, a more meaningful metric can be developed. These challenges are explored, and recommendations are proposed for administration and research that include reconstructing and applying a new perspective on turnover to inform and evaluate initiatives that can reduce the impact of dysfunctional turnover within public child welfare organizations.
\end{abstract}

Keywords: Public child welfare; turnover; retention

Turnover has been identified as a major problem for public child welfare organizations (Weaver, Chang, Clark, \& Rhee, 2007; Williams, Nichols, Kirk, \& Wilson, 2011). Over the last 30 years, child welfare organizations have consistently struggled to develop new initiatives to improve workforce quality and stability (Ball \& Dexheimer, 2015). In this paper we assert that it is time to examine the "problem" of turnover from a new perspective. By critically questioning how turnover is socially constructed, measured, and addressed, a more meaningful metric can be developed. The concept of turnover can be redefined in a way that captures its heterogeneity. Specific recommendations are made for initiatives designed not necessarily to reduce the rate of turnover, but rather to reduce the impact of unhealthy turnover. Based on this new perspective, recommendations are provided for administration and research for public child welfare agencies across the United States.

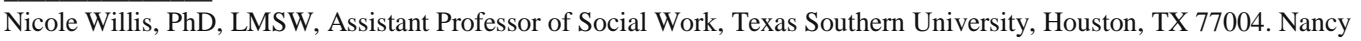
Chavkin, PhD, LMSW-AP, Regents' Professor and Director of the Center for Children and Families, School of Social Work, Texas State University, San Marcos, TX 78666. Patrick Leung, PhD, Professor and Director of the Office for International Social Work Education, Graduate College of Social Work, University of Houston, Houston, TX, 77004.

Copyright @ 2016 Authors Vol. 17 No. 2 (Fall 2016), 116-133, DOI: 10.18060/20856
} 


\section{Texas-Sized Turnover: The Social Construction}

The national turnover rate for child welfare workers has been described as a "chronic problem" (Strolin-Goltzman, 2008, p. 125) and varies between 20-40\% annually (National Child Welfare Workforce Institute, 2011; National Council on Crime and Delinquency, 2006). Statistics that demonstrate high turnover can be found in a variety of sources, such as government documents, peer-reviewed journal articles, and even local newspapers spanning time periods and geographic locations. For example, some headlines read, "Review: CPS hobbled by bureaucracy, high turnover" (Rosenthal, 2014, para. 1), "Florida child-welfare agencies battling high staff turnover-80\% in some parts of state" (Menzel, 2014, para. 1), "Workforce issues continue to plague child welfare" (Riggs, 2007, para. 1), "We suck the passion out of employees: Turnover among caseworkers a product of low salaries, high stress; Agency hopes latest overhaul will change culture" (Ball \& Dexheimer, 2015, para. 1). Such language used in communicating turnover statistics impacts a variety of public child welfare stakeholders.

The magnitude of turnover has fueled a sense of urgency on the part of researchers to understand variables that contribute to turnover, including individual and organizational variables (Strolin-Goltzman et al., 2009; Williams \& Glisson, 2013), as well as the health of the economy (Strolin-Goltzman, 2008; Texas Department of Family and Protective Services [TDFPS], 2012). High turnover statistics have motivated public child welfare administrators to develop initiatives to reduce turnover (Ball \& Dexheimer, 2015) and can be a deterrent in the recruitment of highly qualified employees (Burstain, 2009; The Stephen Group, 2014). Although most would agree that the rate of turnover appears high, it is possible that the common metrics used to measure turnover have led to a social construct that lacks meaningfulness.

\section{A Texas Template: Department of Family and Protective Services}

The public child welfare system in Texas has struggled to understand and address turnover, and these challenges are similar to the experiences of public child welfare systems in other states. In Texas, the turnover rate for public child welfare is approximately 26\% (Texas Department of Family and Protective Services [TDFPS], 2015). This rate increased from 20\% in 1980 (Martinez, 2014) to 25.5-33\% in 2015 (Ball $\&$ Dexheimer, 2015). These rates are particularly high for Child Protective Services (CPS) workers in the Investigations Unit, with a 30-41\% turnover rate (Martinez, 2014; McClure, 2008; TDFPS, 2015). TDFPS workers report leaving their job due to workrelated stress $(21.2 \%)$, lack of satisfaction with pay (14.3\%), and collegial conflicts (12.6\%; Martinez, 2014). Of 200 new CPS hires each month, more than 30 terminated employment within six months of their start date (Ball \& Dexheimer, 2015). These data have driven efforts designed to reduce turnover.

A variety of interventions to address turnover have been implemented in various areas of the Texas public child welfare system. In 2008 CPS implemented a $\$ 5,000 /$ year stipend for workers to go into the Investigations Unit. However, even after the initiative, the turnover rate among Investigators remained around 33\% (Burstain, 2009). Title IV-E programs have built relationships between BSW/MSW programs and public child welfare 
to recruit more highly qualified new hires (TDFPS, 2015). A mentoring program for new caseworkers and strengths-based supervisor training were recently implemented to address turnover (Ball \& Dexheimer, 2015; TDFPS, 2015). A rewards program was also piloted, in which employees recognized by supervisors for excellence could earn administrative leave or wear blue jeans to work. In the 2005 Texas Senate Bill 6 on child welfare reform, TDFPS was required to hire ahead or recruit new employees prior to vacancies (Burstain, 2009). In addition, the Texas State Auditor's Office developed a State of Texas Employee Exit Survey to collect data from workers terminating employment in order to better respond to retention needs (Keel, 2014). Despite such initiatives, turnover rates have not significantly declined.

The challenges that the public child welfare system in Texas has experienced are not isolated situations. Public child welfare employees in neighboring states face the same challenges (Martinez, 2014; TDFPS, 2012), and these challenges are reflected in child welfare literature (Strolin-Goltzman, 2008). In a national survey of public child welfare workers in 17 states, workers reported experiencing low salaries, high caseloads, safety risks, staff shortages, as well as insufficient training and supervision (U.S. General Accounting Office [USGAO], 2003). In a study of 260 public child welfare workers in Georgia, the majority reported feeling burned out, having an unreasonable workload, being unsatisfied with salary, and taking steps to look for employment elsewhere (Williams et al., 2011). These factors are commonly associated with either intent to leave or actual turnover in public child welfare organizations. A wealth of studies have demonstrated that various factors such as burn-out, change of career goals (Dickinson \& Perry, 2002; Graef \& Hill, 2000), dissatisfaction with work environment, lack of commitment to agency, lack of supervisor support (Cahalane \& Sites, 2008; CollinsCamargo \& Royse, 2010; Dickinson \& Perry, 2002; Freund, 2005; MorBarak, Nissly, \& Levin, 2001; Morrison, Burke, \& Greene, 2007) and attractiveness/availability of jobs at other agencies (Dickinson \& Perry, 2002; Maertz \& Campion, 2004; USGAO, 2003) impact both cognitive and behavioral components of turnover. Turnover in public child welfare is complicated, and states across the country struggle to address this issueespecially since turnover can impact the quality of services provided to our most vulnerable children and families (Faller, Grabarek, \& Ortega, 2009; Shim, 2010).

\section{Conventional Definition of Turnover}

It is first important to understand how the construct of turnover has been defined and measured. There are various ways in which turnover has been computed, but in general, those computations include a homogeneous perspective. For example, the conventional calculations include dividing the number of workers who leave employment during a fiscal year by the average number of workers for that same fiscal year (Glebbeek \& Bax, 2004). The average number of workers, for example, can be calculated by totaling the number of workers for each quarter, and dividing by four (Keel, 2014). In Texas, there are two types of measures used in public child welfare. The first includes a measure outlined by the Legislative Budget Board (LBB), which includes all full-time workers who left during the period without returning divided by the average number of full-time workers on the last day of every quarter in that particular period (Burstain, 2009). The 
second measure includes a metric used by the State Auditor's Office, in which turnover rate is calculated by dividing the number of workers who leave during that fiscal year by the average number of workers for that fiscal year (Keel, 2014). There is some variation, but the general interpretation is the same. For example, if a public child welfare agency had an average of 100 workers in 2015 and 30 of them left that year, the turnover rate would be calculated as 30\%. Subsequently, that agency might be described as "hobbling," "plagued," and "sucking passion out of employees."

\section{A Critique of the Turnover Construct}

The conventional construct of turnover in the United States has several weaknesses. Calculation of turnover in public child welfare does not incorporate the heterogeneity of the construct (Heavey, Holwerda, \& Hausknecht, 2013). In business and management literature, many explain that measuring turnover as a rate is not the best way to measure a construct (Muñoz \& Villalobos, 2002). Developing a more meaningful metric of turnover can lead to improved understanding, research, and development of initiatives in public child welfare.

\section{Lacks Multi-Dimensionality}

Turnover rates typically reflect only the unidimensionality of job termination (i.e., leaving or staying). This lacks information about the circumstances under which a worker leaves employment, including their motivation and initiation. The dimension of motivation includes information about the reason for leaving employment. Employment termination can be considered preventable or unpreventable (Strolin-Goltzman, 2008). Unpreventable turnover includes workers who leave their organization for reasons such as job relocation of spouse, return to school, marriage, parenting, death, or retirement. Preventable turnover includes workers who leave for other reasons (e.g., work-related stress, dissatisfaction with salary, work relationships, workload, or lack of goodness-offit). Another dimension of turnover includes initiation, that is, who initiated the termination. For example, turnover can also be categorized as voluntary or involuntary (Kammeyer-Mueller, Wanberg, Glomb, \& Ahlburg, 2005; Keel, 2014; U.S. Department of Labor [USDL], 2016). Employees initiate voluntary types of termination, which include the employee making the decision to terminate, regardless of reason for leaving. On the other hand, involuntary terminations are those initiated by the employer, for reasons such as poor performance, agency downsizing, or expired agency contracts (McElroy, Morrow, \& Rude, 2001). Workers who transfer within the agency or to another state agency are sometimes excluded from the turnover construct, as some do not consider it a loss to the state as a whole (Keel, 2014). However, Burstain (2009) explained that turnover measures should include not only those who leave the agency, but also those who transfer to other positions within the agency, since this also disrupts the worker-client relationship. Keel (2014) found that turnover rate for the TDFPS was $18.8 \%$ using the traditional metric. However, if involuntary turnover were excluded, the turnover rate would fall to $14.8 \%$. Keel (2014) asserts that excluding involuntary turnover would be a more accurate measure of turnover. 
Turnover rates also do not take into account an employee's length of service or employee value to the agency (Buchan, 2010; Muñoz \& Villalobos, 2002). For example, an overall turnover rate could either reflect that all employees left the agency in one year, or that $25 \%$ of them left the agency each quarter. This limits insight regarding employment longevity among staff (Buchan, 2010). In addition, some studies (e.g., Kammeyer-Mueller et al., 2005; The Stephen Group, 2014; Strolin-Goltzman et al., 2009) included both low and high performing employees in the same turnover variable. This creates a challenge with drawing accurate conclusions about the impact of turnover on an organization, since losing a high-performing employee can have a more negative consequence on agency performance than losing a low-performing employee.

\section{Lacks Distinction: Functional versus Dysfunctional}

According to Staw (1980), the misperception that turnover is negative has been driven by assumptions, including the saliency of associated costs. A multidimensional perspective could help distinguish turnover that is functional (not harmful) from turnover that is dysfunctional (harmful). According to Smith and Rutigliano (2002), the organizational cost of a $15 \%$ turnover rate depends on the type of workers that figure represents. In other words, losing $15 \%$ of high-performing employees will have a very different cost to the organization than losing $15 \%$ of low-performing employees.

Although research has found that turnover is costly to public child welfare agencies (Graef \& Hill, 2000), the failure to incorporate multidimensionality into the social construct of turnover inflates the perceived rates and costs to the agency. The impact of turnover has been examined in terms of hard costs (e.g., administrative time, advertising open positions, interviewing potential new hires, drug and background checks, new employee orientation, etc.) and soft costs (lost productivity of employees who left the agency, employee's colleagues and supervisors) (Graef \& Hill, 2000; McClure, 2008). McClure estimates the total cost to TDFPS for each child welfare worker who quits to be more than $\$ 52,500$. Based on the turnover of more than 1,000 child welfare workers in 2006, McClure (2008) estimated that TDFPS experienced a loss of more than \$56 million that year. However, the actual costs to public child welfare agencies may be inflated due to the way in which turnover is conceptualized.

\section{How Assumptions Have Driven Research}

\section{The Linear Perspective}

Research has consistently reported that turnover is dysfunctional (negative) and associated with poor organizational outcomes while assuming that this relationship is linear. The assumption that turnover damages client outcomes and organizational effectiveness through a loss of financial and social capital have driven the bulk of the literature, especially in public child welfare (Heavey et al., 2013). National child welfare outcomes have been established by the U.S. Department of Health and Human Services (2016) and include reducing: recurrence and incidence of child abuse/neglect, time between foster care and reunification, time between foster care and adoption, and placements of youth in group homes/institutions, as well as increasing permanency for 
youth in foster care and placement stability. Some research has found that high turnover is correlated with difficulty in meeting the standards for client outcomes, such as increases in foster care placements (Strolin-Goltzman, Kollar, \& Trinkle, 2010), delays in plan approvals for both keeping children in the home and family reunification, increases in substantiated re-abuse or re-neglect (National Council on Crime and Delinquency, 2006) and reduced permanency (Leung, 2008; Martinez, 2014). In addition, increased turnover has also been associated with poor agency fiscal health (Cahalane \& Sites, 2008; Folaron \& Hostetter, 2007; Landsman, 2007; Rosenthal \& Waters, 2006). However, some research, especially in the business and management disciplines, suggests that the assumptions that drive turnover research in public child welfare may not capture the whole picture.

Research has found that relationships between turnover and organizational effectiveness are weak and curvilinear, even if statistically significant. Studies have also found that the impact of turnover on organizational performance is small (Huselid, 1995; Koys, 2001). For example, Heavey et al. (2013) found that the relationships between voluntary and involuntary turnover, customer satisfaction, and organizational efficiency were weak $(r=.20, r=-.35)$, even though statistically significant. Other research challenges the assumption that the relationship between turnover and organizational outcomes is linear. Glebbeek and Bax (2004) found that turnover explained less than 19\% of the variance in organizational performance and that this relationship was curvilinear. Siebert and Zubanov (2009) also found a curvilinear relationship between turnover and organizational productivity, but this was specific to the type of worker. Furthermore, in a national study of 73 child welfare agencies, Williams and Glisson (2013) found that a decrease in caseworker turnover was not associated with improved child outcomes in all child welfare agencies. In fact, decreases in turnover only improved child outcomes in agencies that had high organizational proficiency (agencies characterized by having norms/expectations that focus on clients' well-being) and workers with current knowledge/skills who respond effectively to client needs and contribute to positive client outcomes (Williams \& Glisson, 2013). Within agencies that had low organizational proficiency, decreases in turnover had no significant impact on child welfare outcomes. These findings provide some evidence that challenges the linear relationship between turnover and both client and organizational outcomes in public child welfare agencies.

\section{Turnover and Organizational Health}

Although turnover is generally associated with workforce stability (Buchan, 2010; Burstain, 2009), low turnover rates are not always an indicator of organizational health. Our current perception of turnover limits its value to an agency because negative consequences of turnover receive more attention than positive ones (Staw, 1980). In large organizations, turnover can be quite natural and healthy in several ways. Retirement, death, relocation, or leaving due to illness are all natural forms of attrition, expected in any organizational system. Transferring to other departments or to other state agencies is also common and can be expected. In addition, hiring and/or retaining employees who are not a good fit for providing services in public child welfare can have negative impacts on the health of the organization. 
Research has found that low turnover rates are highly correlated with the overall health of the job market (Kenny, 2007). Burstain (2009) and the TDFPS (2012) found that turnover in public child welfare is lower during periods of stagnation in the economy. For example, it is plausible that workers who are unfit or unmotivated to work are more likely to remain employed in public child welfare when the job market is stagnant and the prospect of working elsewhere is limited. On the surface, higher retention might appear to be a success and be interpreted as less costly to the agency (Staw, 1980). However, retention of workers whose turnover would be considered desirable could also have a negative impact on the agency's fiscal health and client outcomes (Mowday, 1984; Park \& Shaw, 2013; Smith \& Rutigliano, 2002).

The public child welfare system is unique in nature, and some people are not a good fit as employees. In fact, TDFPS $(2012,2015)$ found that $19-25 \%$ of applicants are not recommended for this type of work based on their pre-employment screening. The work-life fit is a strong predictor of intent to leave, regardless of working in a high or low turnover agency (Strolin-Goltzman, 2008). Managing bureaucracy, constant organizational change, lower pay in exchange for responding to allegations of maltreatment, identifying needs, and providing services makes this professional environment suited to particular types of employees (Wells, Jolles, Chuang, McBeath, \& Collins-Camargo, 2014). High turnover can also be a characteristic of specific types of organizational systems (Mowday, 1984). Therefore, higher turnover might be a reasonable and expected component of public child welfare organizations.

Due to the stressful nature of public child welfare, the average length of tenure could be considered expected, compared to other jobs, in general. Graef and Hill (2000) state that "long-term employment is not the norm for many child protection staff" (p. 519). Some workers leave because they recognize they are not a good fit and cannot contribute to a healthier organization (Strolin, McCarthy, \& Caringi, 2007). Turnover is highest in the first three months of employment when training occurs (TDFPS, 2015). The timing of worker departure can inflate overall rate of turnover and costs to the organization. The reasons those who quit before the three month training ends can have an influence on the health of the organization. For instance, employees might realize the job is not a good fit, might not perform well during exercises, may not have realized what the job entailed, etc.; thus, the bulk of turnover in the first three months could be considered healthy. In 2012, the average length of employment of child welfare workers was four years in Texas (TDFPS, 2012). This is similar to tenure in other states. In a national sample of over 9,000 public child welfare workers, the average length of employment was less than four years (Madden, Scannapieco, \& Painter, 2014). In a national study of almost 2,000 child welfare workers, Barth, Lloyd, Christ, Chapman, and Dickinson (2008) found that the average tenure in employment was approximately seven years. Furthermore, StrolinGoltzman (2008) found that employee tenure at low turnover agencies was only two years higher than at high turnover agencies. Retaining workers for the sake of having low turnover rates can be more costly to organizations if workers are unmotivated, burned out, and/or lack goodness-of-fit (Abelson \& Baysinger, 1984). Furthermore, turnover makes room for new hires that bring fresh ideas and savings on salary expenditures (Abelson \& Baysinger, 1984; Park \& Shaw, 2013). 


\section{Recommendations for Administration and Research}

Research shows that most public child welfare agencies have a goal to reduce overall levels of turnover (Rosenthal \& Waters, 2006; Strolin-Goltzman, 2008; USGAO, 2003). This is driven by the perception that turnover is unhealthy, leading to initiatives to reduce its overall magnitude. This is in and of itself somewhat problematic, due to lack of consensus regarding rates of turnover, recognition that some types of turnover are healthy, and the nature of public child welfare work.

New dialogue about turnover in public child welfare needs to come from a perspective of health and meaning. There is evidence that: (a) the way we measure turnover is not as meaningful as it could be, and (b) there have been many preventive initiatives in the last 30 years with no major changes to turnover (Ball \& Dexheimer, 2015; TDFPS, 2015). Our knowledge base will stagnate if research and practice have a one-dimensional view of turnover. For example, turnover rates in public child welfare will continue to be reported as "crippling" in public and professional circles, which is a deterrent in recruitment efforts of highly qualified employees. If research continues to examine turnover in terms of linearity and homogeneity, our understanding of this phenomenon will remain limited. Administrators will continue to incorporate a onedimensional perspective of turnover and develop practice initiatives that have little impact on turnover. However, a new perspective could redefine the social construct of turnover and focus on reducing the impact (not overall rate) of turnover. Therefore based on the research reviewed herein, we present the following three recommendations to reduce the impact of dysfunctional turnover, 1) set realistic goals for optimal years of service, based on the unique nature of public child welfare work, 2) monitor and report on meaningful turnover in public child welfare, and 3) develop initiatives to minimize the impact of turnover instead of minimizing overall rate of turnover.

\section{Recommendation \#1: Set Realistic Goals for Optimal Years of Service, Based on the Unique Nature of Public Child Welfare Work}

Although retention is a desirable outcome, the length of retention has not been standardized in turnover literature. For example, how many years are ideal for a caseworker to remain employed in public child welfare? Providing services to vulnerable children and families in public child welfare requires workers to apply specialized skills, knowledge, and values with competence and compassion. Working in an environment with increasing caseloads, low pay, and daily exposure to issues such as abuse and neglect is stressful (Martinez, 2014). The burden of emotional stress may occur at a faster rate than other types of employment, impacting the length of employment in this field. In addition, the average American person will have more than seven jobs before 33 years of age (Kenny, 2007). However, Barth et al. (2008) argue that the average length of employment of seven years is a "cause for concern" (p. 208), and that longer tenure is key in a field like public child welfare. Although research demonstrates that two to seven years of service in public child welfare is the norm, what is normal may or may not be optimal. Optimal tenure length is not clearly defined and should be further explored in future research focused on caseworkers who are "in the trenches" and deliver services within departments that traditionally have the highest level of instability (Burstain, 2009). 
Future research among U.S. public child welfare agencies should explore relationships between public child welfare roles and optimal years of service. In addition, cost-benefit analyses can examine the impact of dysfunctional turnover in terms of organizational hard and soft costs. This can be used to establish optimal turnover rates within individual organizations.

\section{Recommendation \#2: Monitor and Report on Meaningful Turnover in Public Child Welfare}

Research has demonstrated that there are various dimensions of turnover, persons who initiate the turnover (voluntary/involuntary), reasons for leaving (avoidable/unavoidable), and proximity (intra/inter-agency transfer/no transfer). However, it is the one-dimensional rate of turnover that is most often reported and associated with negative impact on agency outcomes. A new perspective on turnover should incorporate heterogeneity and allow differentiation of functional (healthy) turnover from dysfunctional (unhealthy) turnover. Resources have been allocated to develop and implement preventive initiatives, such as mentoring; however, incentives have generally not been tailored to the multi-dimensionality of turnover. In fact, Staw (1980) asserts that allocating resources equally among low and high performing workers is more likely to result in unhealthy turnover of high-performing employees than low performers. Therefore, these resources are likely to prevent healthy turnover (i.e., increased retention of workers who are disengaged, not a good fit, etc.) and would be inefficiently spent on unavoidable turnover (i.e., turnover due to illness, retirement, etc.).

Research and practice initiatives should focus on the turnover that has the most negative impact on child welfare organizations. Some studies have attempted to test the association between voluntary and involuntary turnover with organizational attributes (e.g., Hausknecht, Trevor, \& Howard, 2009; Kammeyer-Mueller et al., 2005; Keel, 2014; McElroy et al., 2001). However, current research that examines voluntary turnover has included those employees with both low and high performance (Park \& Shaw, 2013). Including both low- and high-performing employees in the same category makes it difficult to draw conclusions about the impact of turnover on an organization (Hausknecht et al., 2009; Mowday, 1984). Partitioning turnover into voluntary and involuntary categories might limit our measures, as it leaves out the distinct interaction with other dimensions of turnover. The dynamic relationship between worker performance and turnover is an important direction for future studies (KammeyerMueller et al., 2005). In order to determine what is considered healthy and unhealthy, research should include worker performance as an additional dimension of turnover rates. Abelson and Baysinger (1984) suggest coding functional turnover for those with low performance scores who leave and dysfunctional turnover for those with high performance scores who leave. The interaction between worker performance and turnover characteristics - for those workers who remain past the probationary/training period-will help to produce a more meaningful metric about the level of turnover considered unhealthy to the organization.

In order to create a more meaningful metric, public child welfare organizations in the United States can integrate some of the instruments that already exist. For example, the 
TDFPS (2012, 2015) administers the State of Texas Employee Exit Survey when employees leave the agency and has developed a new performance evaluation. The exit interviews were designed to gather more information about employee motivations and types of turnover. However, completion of both of these evaluations is optional. While the majority $(79 \%)$ complete the performance evaluation, less than $15 \%$ of employees complete the exit interview (TDFPS, 2012, 2015). Exit interview data could indicate motivation and initiation of turnover and could be combined with the employee performance data to create a richer multidimensional view of turnover (see Table 1).

Providing incentives for completing the exit interview (e.g., gift cards, etc.) could yield a higher response rate, and thus, increase the generalizability of the results. A change in how turnover data is defined and collected would require public child welfare administrators to invest significant resources into creating and administering annual performance reviews for each worker, deciding cut-off scores for those reviews, and developing a systematic way to collect and integrate data from each worker's performance score and turnover type. There may be a lack of administrative and/or financial resources at some agencies to implement this type of data collection and analysis.

Table 1. Functional/Dysfunctional Metric of Organizational Turnover

\begin{tabular}{|l|l|l|l|}
\hline $\begin{array}{l}\text { Type of } \\
\text { Turnover }\end{array}$ & Characteristic & Low performance & High performance \\
\hline Preventable & $\begin{array}{l}\text { Dissatisfied with pay, lack } \\
\text { of collegial relationships }\end{array}$ & Functional (+) & Dysfunctional (-) \\
\hline $\begin{array}{l}\text { Unpreventable/ } \\
\text { Voluntary }\end{array}$ & $\begin{array}{l}\text { Death, relocation of } \\
\text { spouse, illness, retirement, } \\
\text { intra-agency transfer }\end{array}$ & Functional (+) & Dysfunctional (-) \\
\hline Involuntary & $\begin{array}{l}\text { Laid off, fired, expired } \\
\text { employment contracts }\end{array}$ & Functional (+) & Dysfunctional (-) \\
\hline
\end{tabular}

Turnover is a complicated construct that has distinct interaction effects. For example, although retirement is voluntary/unpreventable, the impact of this type of turnover depends on the level of worker performance. Similarly, the impact of turnover due to pay dissatisfaction of a high performer is different on the organization than turnover of a lowperforming worker who leaves for preventable reasons.

Previous initiatives have been designed to reduce turnover; however, literature in business and management has demonstrated that organizational effectiveness is low in both very low rates of turnover and very high rates (Abelson \& Baysinger, 1984). Glebbeek and Bax (2004) tested this model in a staffing firm with over 1,800 employees, controlling for absenteeism, age, and region; they found that both extremely low and high turnover have a negative impact on organizational performance. The turnover explained less than $19 \%$ of the variance in organizational performance. Turnover can only be considered dysfunctional if it takes away from overall organizational effectiveness.

Once public child welfare agencies use integrated data to create a more meaningful metric that estimates dysfunctional turnover, an optimal turnover rate can be determined 
to inform practice initiatives. An optimal turnover rate is "the rate that minimizes the sum of the costs of turnover plus the costs associated with reducing it" (Abelson \& Baysinger, 1984, p.333). Currently, there is a lack of consensus about what is considered low and high, or acceptable and unacceptable rates of turnover in public child welfare. Some research utilized an arbitrary cut-off to distinguish agencies with low rates (17\% or less turnover) from agencies with high rates (greater than 17\% turnover; e.g. Keel, 2014; Strolin-Gotzman, 2008). According to Strolin-Goltzman et al. (2010), an annual turnover rate greater than $25 \%$ is considered "high." In the business industry, a turnover rate of up to $15 \%$ is considered optimal and healthy (Schreiner, n.d.; Siebert \& Zubanov, 2009). "High turnover" is a term used to describe the rates in most public child welfare agencies (Auerbach, Schudrich, Lawrence, Claiborne, \& McGowan, 2014), but it is not useful to describe all turnover as high and interpret such rates as entirely negative.

In complex organizational systems, the optimal turnover rate will vary by agency because there is no standard of turnover (Abelson \& Baysinger, 1984) and will even be higher in lower-level positions within the agency itself (Mowday, 1984). Public child welfare agencies across the United States can integrate their existing data collection instruments or develop instruments that provide a metric that distinguishes functional and healthy turnover from dysfunctional and unhealthy turnover. This will likely reduce the rate of turnover that is reported to the public, and thus, could result in a more positive organizational image. A more positive image of public child welfare can help attract highly qualified candidates for positions within the agencies, as well as improve worker morale (Burstain, 2009). A better understanding of dysfunctional turnover can also help to inform practice initiatives targeting turnover deemed to have a negative impact on outcomes.

\section{Recommendation \#3: Develop Initiatives to Minimize the Impact of Turnover Instead of Minimizing Overall Rate of Turnover}

The reality of the public child welfare industry is that organizations are inclined to high turnover. Therefore, organizations should develop initiatives that reduce the impact of high turnover. In business and management organizations, specific strategies are used to mitigate turnover impacts, such as buffering, smoothing, and forecasting (Mowday, 1984).

These same approaches might be adapted for the public child welfare organizations across the United States. In business, buffering includes reducing the disruption of turnover by implementing "strategies that increase the organizational resources beyond a level minimally required to complete a task" (Mowday, 1984, p. 371), which introduces slack in the organizational system. Agencies could create a new metric to assess dysfunctional turnover at the departmental level, and can then identify high priority systems with the most need for initiatives. For example, one initiative in Texas was the practice to hire ahead of vacancies. However, this would be challenging when there are excessive vacancies to fill in departments with high turnover. Instead, a strategy to reduce the impact of high turnover might be to overstaff that particular department. For example, if the Investigations Unit had the highest level of dysfunctional turnover, the organization could over-hire to create additional slack when a worker leaves. However, as public child 
welfare agency budgets are already strained - many by inadequate state funding - this approach might be met with resistance, as it would increase the operating costs for many agencies.

Another way to use buffering to reduce the impact of turnover is cross-training employees (Mowday, 1984). Although cross-training is not common in public child welfare agencies, the American Public Human Services Association (2010) recommends cross-training as one of its key strategies for improving child welfare outcomes. In public child welfare, cross-training for skills used in other departments will allow mobility in departments with the lowest dysfunctional turnover to fill in departments with the highest dysfunctional turnover. An examination of historical trends within each specific department in an agency can help inform this strategy (Mowday, 1984). Traditionally, workers in the same department absorb extra caseloads until an additional person is hired and trained. However, application of cross-training might help to reduce the impact of dysfunctional turnover. Mowday (1984) suggests redefining job titles to allow for more flexibility to achieve cross-training movement.

Turnover research has contributed to the development of process models (i.e., describing how workers leave/remain employed) and content models (i.e., why workers leave/remain employed (Maertz \& Campion, 2004). Research suggests that variables from the individual to the organizational levels influence intent to leave, decisions to stay, and actual retention and turnover rates (Gansle \& Ellett, 2002; Jacquet, Clark, Morazes, \& Withers, 2007; Zlotnik, DePanfilis, Daining, \& Lane, 2005). However, one limitation to this research is that the unit of analysis is on individual processes and behaviors. Although substantial knowledge about how and why a worker leaves public child welfare has been developed, there is limited knowledge about these processes in terms of the fluidity of turnover between persons.

A new perspective on turnover can drive different units of analysis for research. Future research can examine the differences in the turnover process between those who leave and those who stay (i.e., the interpersonal component of turnover) to build on existing research about the intrapersonal cognitive and behavioral processes of turnover. In a study by Willis (2010), qualitative comments by public child welfare workers suggested that a more fluid transition process with leavers/new hires will alleviate stress, absorption of extra caseloads, changing relationships, and overtime work hours. In another study, Strolin-Goltzman et al. (2010) found that foster youth corroborated the need to focus on the fluidity of transition between workers during turnover, in order to maintain trust in the worker-client relationship. Once organizational initiatives are developed to reduce the impact of dysfunctional turnover, research studies can be conducted to measure interpersonal processes in public child welfare agencies across the United States. Evaluating interpersonal processes (i.e., cross-training) can add to current knowledge about process and content models of turnover. The well-being of the children and families served in the public child welfare system is the top priority, yet a large knowledge gap currently exists in our understanding about the nature of the relationship between turnover and client outcomes in public child welfare (Williams \& Glisson, 2013). Researchers can collaborate with agency administrators to explore the relationship between approaches to reduce the impact of turnover on child welfare outcomes. 


\section{Conclusion}

Although a variety of initiatives have been implemented in the last 30 years, the headlines about high turnover in public child welfare have persisted. New headlines and new perspectives need to be created. Future research initiatives that focus on the multidimensional approach to turnover can better inform efforts to redefine the public image of turnover in the public child welfare system. Recognizing that public child welfare organizations are different than traditional businesses, it is imperative that constructs, measures, and initiatives that are evidence-based in business/management disciplines are carefully evaluated and adapted to be culturally appropriate for public child welfare organizations. Applying interdisciplinary knowledge and approaches can help us find new ways to understand and address the turnover problem that has "plagued" the public child welfare system for the last 30 years. A new perspective that recognizes and responds to the heterogeneity of turnover can lead to a more meaningful turnover construct that contributes to a more positive public image, development of useful practice initiatives, new directions for research, and ultimately, better outcomes for the children and families that we serve.

\section{References}

Abelson, M.A., \& Baysinger, B.D. (1984). Optimal and dysfunctional turnover: Toward an organizational level model. Academy of Management Review, 9(2), 331-341.

American Public Human Services Association. (2010). Positioning public child welfare guidance: Strengthening families in the $21^{\text {st }}$ century. Washington, DC: Author.

Auerbach, C., Schudrich, W. Z., Lawrence, C. K., Claiborne, N., \& McGowan, B. G. (2014). Predicting turnover: Validating the Intent to Leave Child Welfare Scale. Research on Social Work Practice, 24(3), 349-355. doi:http://dx.doi.org/10.1177/1049731513494021

Ball, A., \& Dexheimer, E. (2015). "We suck the passion out of employees": Turnover among caseworkers a product of low salaries, high stress; agency hopes latest overhaul will change culture. The Statesman. Retrieved from http://projects.statesman.com/news/cps-missed-signs/turnover.html

Barth, R. P., Lloyd, E. C., Christ, S. L., Chapman, M. V., \& Dickinson, N. S. (2008). Child welfare worker characteristics and job satisfaction: A national study. Social Work, 53(3), 199-209. doi:http://dx.doi.org/10.1093/sw/53.3.199

Buchan, J. (2010). Reviewing the benefits of health workforce stability. Human Resources for Health, 8(29), 1-5. doi:http://dx.doi.org/10.1186/1478-4491-8-29

Burstain, J. (2009). A better understanding of caseworker turnover within child protective services (Research Report No. 09-364). Retrieved from Center for Public Policy Priorities website: http://www.cppp.org

Cahalane, H., \& Sites, E. W. (2008). The climate of child welfare employee retention. Child Welfare, 87(1), 91-114. 
Collins-Camargo, C., \& Royse, D. (2010). A study of the relationships among effective supervision, organizational culture promoting evidence-based practice, and worker self-efficacy in public child welfare. Journal of Public Child Welfare, 4, 1-24. doi:http://dx.doi.org/10.1080/15548730903563053

Dickinson, N. S., \& Perry, R. E. (2002). Factors influencing the retention of specially educated public child welfare workers. Journal of Health \& Social Policy, 15(3/4), 89-103.

Faller, K. C., Grabarek, M., \& Ortega, R. M. (2009). Commitment to child welfare work: What predicts leaving and staying? Children and Youth Services Review, 32, 840846. doi:http://dx.doi.org/10.1016/j.childyouth.2010.02.003

Folaron, G., \& Hostetter, C. (2007). Is social work the best educational degree for child welfare practitioners? Journal of Public Child Welfare, 1, 65-83. doi:http://dx.doi.org/10.1300/J479v01n01_04

Freund, A. (2005). Commitment and job satisfaction as predictors of turnover intentions among welfare workers. Administration in Social Work, 29(2), 5-21. doi:http://dx.doi.org/10.1300/J147v29n02_02

Gansle, K. A., \& Ellett, A. J. (2002). Child welfare knowledge transmission, practitioner retention, and university-community impact: A study of Title IV-E child welfare training. Journal of Health \& Social Policy, 15(3/4), 69-88.

Glebbeek, A. C., \& Bax, E. H. (2004). Is high employee turnover really harmful? An empirical test using company records. Academy of Management Journal, 47(2), 277286. doi:http://dx.doi.org/10.2307/20159578

Graef, M. I., \& Hill, E. L. (2000). Costing child protective services staff turnover. Child Welfare, 129(5), 517-533.

Hausknecht, J. P., Trevor, C. O., \& Howard, M. J. (2009). Unit-level voluntary turnover rates and customer service quality: Implications of group cohesiveness, newcomer concentration, and size. Journal of Applied Psychology, 94(4), 1068-1075. doi:http://dx.doi.org/10.1037/a0015898

Heavey, A. L., Holwerda, J. A., \& Hausknecht, J. P. (2013). Causes and consequences of collective turnover: A meta-analytic review. Journal of Applied Psychology, 98(3), 412-453. doi:http://dx.doi.org/10.1037/a0032380

Huselid, M. A. (1995). The impact of human resource management practices on turnover, productivity, and corporate financial performance. Academy of Management Journal, 38, 635-672. doi:http://dx.doi.org/10.2307/256741

Jacquet, S. E., Clark, S. J., Morazes, J. L., \& Withers, R. (2007). The role of supervision in the retention of public child welfare workers. Journal of Public Child Welfare, 1(3), 27-28. doi:http://dx.doi.org/10.1300/J479v01n03_03 
Kammeyer-Mueller, J. D., Wanberg, C. R., Glomb, T. M., \& Ahlburg, D. (2005). The role of temporal shifts in turnover processes: It's about time. Journal of Applied Psychology, 90(4), 644-658. doi:http://dx.doi.org/10.1037/0021-9010.90.4.644

Keel, J. (2014). An audit report on caseload and staffing analysis for child protective services at the Department of Family and Protective Services (Report No. 13-036). Retrieved from http://www.sao.texas.gov/reports/main/13-036.pdf

Kenny, B. (2007). The coming crisis in employee turnover. Forbes Magazine. Retrieved from http://www.forbes.com/2007/04/24/employees-turnover-careers-lead-careerscz_bk_0425turnover.html

Koys, D. J. (2001). The effects of employee satisfaction, organizational citizenship behavior, and turnover on organizational effectiveness: A unit-level, longitudinal study. Personnel Psychology, 54, 101-114. doi:http://dx.doi.org/10.1111/j.17446570.2001.tb00087.x

Landsman, M. (2007). Supporting child welfare supervisors to improve worker retention. Child Welfare, 86(2), 105-124.

Leung, P. (2008). The impact of child welfare training on case outcomes. Presented to the Texas House Human Service Committee Hearing in Arlington, Texas on February 21, 2008.

Madden, E. E., Scannapieco, M., \& Painter, K. (2014). An examination of retention and length of employment among public child welfare workers. Children and Youth Services Review, 41, 37-44. doi:http://dx.doi.org/10.1016/j.childyouth.2014.02.015

Maertz, C. P., \& Campion, M. A. (2004). Profiles in quitting: Integrating process and content turnover theory. Academy of Management Journal, 47(4), 566-582. doi:http://dx.doi.org/10.2307/20159602

Martinez, D. (2014, September 10). Presentation to House of Representatives Select Committee on Child Protection: Turnover of CPS workers. Presented at the House of Representatives Select Committee on Child Protection, Austin, TX.

McClure, M. (2008, February). Stabilization and permanency of children in foster care. Presented at the House Human Services Committee Hearing, Austin, TX.

McElroy, J. C., Morrow, P. C., \& Rude, S. C. (2001). Turnover and organizational performance: A comparative analysis of voluntary, involuntary, and reduction-inforce turnover. Journal of Applied Psychology, 86, 1294-1299. doi:http://dx.doi.org/10.1037/0021-9010.86.6.1294

Menzel, M. (2014, September 8). Florida child-welfare agencies battling high staff turnover $-80 \%$ in some parts of state. The Florida Times-Union. Retrieved from http://jacksonville.com/news/2014-09-08/story/florida-child-welfare-agenciesbattling-high-staff-turnover-80-percent-some

MorBarak, M., Nissly, J., \& Levin, A. (2001). Antecedents to retention and turnover among child welfare, social work, and other human service employees: What can we 
learn from past research? A review and metanalysis. Social Service Review, 75(4), 625-661. doi:http://dx.doi.org/10.1086/323166

Morrison, E. E., Burke III, G. C., \& Greene, L. (2007). Meaning in motivation: Does your organization need an inner life? Journal of Health \& Human Services Administration, 30(1), 98-115.

Mowday, R. T. (1984). Strategies for adapting to high rates of employee turnover. Human Resource Management, 23(4), 365-380. doi:http://dx.doi.org/10.1002/hrm.3930230404

Muñoz, L. F., \& Villalobos, J. R. (2002). Work allocation strategies for serial assembly lines under high labour turnover. International Journal of Production Research, 40(8), 1835-1852. doi:http://dx.doi.org/10.1080/00207540210123625

National Child Welfare Workforce Institute. (2011, April). Child welfare workforce demographics (2000-2010): Snapshot of the frontline child welfare caseworker. Retrieved from https://ncwwi.org/files/Workforce Demographic Trends May2011.pdf

National Council on Crime and Delinquency. (2006). Relationship between staff turnover, child welfare system functioning and recurrent child abuse. Retrieved from http://www.cpshr.us/workforceplanning/documents/06.02_Relation_Staff.pdf

Park, T., \& Shaw, J. D. (2013). Turnover rates and organizational performance: A metaanalysis. Journal of Applied Psychology, 98(2), 268-309. doi:http://dx.doi.org/10.1037/a0030723

Riggs, D. (2007). Workforce issues continue to plague child welfare. North American Council on Adoptable Children. Retrieved from www.nacac.org/adoptalk/WorkforceIssues.html

Rosenthal, B. M. (2014, June 18). Review: CPS hobbled by bureaucracy, high turnover. The Houston Chronicle. Retrieved from http://www.houstonchronicle.com/news/politics/texas/article/Review-CPS-hobbledby-bureaucracy-high-turnover-5562982.php

Rosenthal, J. A., \& Waters, E. (2006). Predictors of child welfare worker retention and performance: Focus on title IV-E funded social work education. Journal of Social Service Research, 32(3), 67-85. doi:http://dx.doi.org/10.1300/J079v32n03_04

Schreiner, E. (n.d.). What is a healthy employee turnover rate? The Houston Chronicle. Retrieved from http://smallbusiness.chron.com/healthy-employee-turnover-rate$\underline{12145 . h t m l}$

Shim, M. (2010). Factors influencing child welfare employee's turnover: Focusing on organizational culture and climate. Children and Youth Services Review, 32, 847-856. doi:http://dx.doi.org/10.1016/j.childyouth.2010.02.004 
Siebert, W. S., \& Zubanov, N. (2009). Searching for the optimal level of employee turnover: A study of a large U.K. retail organization. Academy of Management Journal, 52(2), 294-313. doi:http://dx.doi.org/10.5465/AMJ.2009.37308149

Smith, B., \& Rutigliano, T. (2002). The truth about turnover. Gallup. Retrieved from http://www.gallup.com/businessjournal/316/truth-about-turnover.aspx

Staw, B. M. (1980). The consequences of turnover. Journal of Occupational Behaviour, 1, 253-273.

The Stephen Group. (2014, June 12). DFPS CPS operational review: Phase 1: Assessment/Findings. Retrieved from https://s3.amazonaws.com/s3.documentcloud.org/documents/1388904/stephens-grpfindings-all.pdf

Strolin-Goltzman, J. (2008). Should I stay or should I go? A comparison study of intention to leave among public child welfare systems with high and low turnover rates. Child Welfare, 87(4), 125-143.

Strolin-Goltzman, J., Kollar, S., \& Trinkle, J. (2010). Listening to the voices of children in foster care: Youths speak out about child welfare workforce turnover and selection. Social Work, 55(1), 47-53. doi:http://dx.doi.org/10.1093/sw/55.1.47

Strolin-Goltzman, J., Lawrence, C., Auerbach, C., Caringi, J., Claiborne, N., Lawson, H.,...Shim, M. (2009). Design teams: A promising organizational intervention for improving turnover rates in the child welfare workforce. Child Welfare, 88(5), 149168.

Strolin, J. S., McCarthy, M., \& Caringi, J. (2007). Causes and effects of child welfare workforce turnover: Current state of knowledge and future directions. Journal of Public Child Welfare, 1(2), 29-52. doi:http://dx.doi.org/10.1300/J479v01n02_03

Texas Department of Family and Protective Services [TDFPS]. (2012). Child protective services salary study. Retrieved from https://www.dfps.state.tx.us/About_DFPS/Reports_and_Presentations/CPS/document s/2012/2012-12-03 DFPS Salary Study HB\%20753.pdf

TDFPS. (2015). Progress report to the Sunset Advisory Commission: Child Protective Services Transformation. Retrieved from https://www.dfps.state.tx.us/About_DFPS/Reports_and_Presentations/CPS/document s/2015/2015-04-30_CPS_Transformation_Metrics.pdf

U.S. Department of Health \& Human Services. (2016). Child welfare outcomes 20102013: Report to Congress: Executive Summary. Retrieved from http://www.acf.hhs.gov/sites/default/files/cb/cwo10_13_exesum.pdf

U.S. Department of Labor, Bureau of Labor Statistics. (2016). Job openings and labor turnover- January 2016 (USDL Publication No. 16-0519). Retrieved from http://www.bls.gov/news.release/pdf/jolts.pdf 
U.S. General Accounting Office. (2003). Child welfare: HHS could play a role in helping child welfare agencies recruit and retain staff. Retrieved from http://www.gao.gov/assets/240/237373.pdf

Weaver, D., Chang, J., Clark, S., \& Rhee, S. (2007). Keeping public child welfare workers on the job. Administration in Social Work, 31(2), 5-25. doi:http://dx.doi.org/10.1300/J147v31n02 02

Wells, R., Jolles, M. P., Chuang, E., McBeath, B., \& Collins-Camargo, C. (2014). Trends in local public child welfare agencies 1999-2009. Children and Youth Services Review, 38, 93-100. doi:http://dx.doi.org/10.1016/j.childyouth.2014.01.015

Williams, N. J., \& Glisson, C. (2013). Reducing turnover is not enough: The need for proficient organizational cultures to support positive youth outcomes in child welfare. Children and Youth Services Review, 35(11), 1-17. doi:http://dx.doi.org/10.1016/j.childyouth.2013.09.002

Williams, S. E., Nichols, Q. I., Kirk, A., \& Wilson, T. (2011). A recent look at the factors influencing workforce retention in public child welfare. Children and Youth Services Review, 33, 157-160. doi:http://dx.doi.org/10.1016/j.childyouth.2010.08.028

Willis, N. (2010). Using systems theory \& social exchange theory to understand factors that impact retention, turnover and motivation to work in a public child welfare agency (Doctoral dissertation). University of Houston, Graduate College of Social Work, Houston, TX.

Zlotnik, J. L., DePanfilis, D., Daining, C., \& Lane, M. M. (2005). Factors influencing retention of child welfare staff: A systematic review of research. Washington, DC: Institute for the Advancement of Social Work Research.

\section{Author note}

Address correspondence to: Nicole Willis, Assistant Professor of Social Work, Texas Southern University, 3100 Cleburne Street, PAB 302Z, Houston, TX 77004 or willisng@tsu.edu 